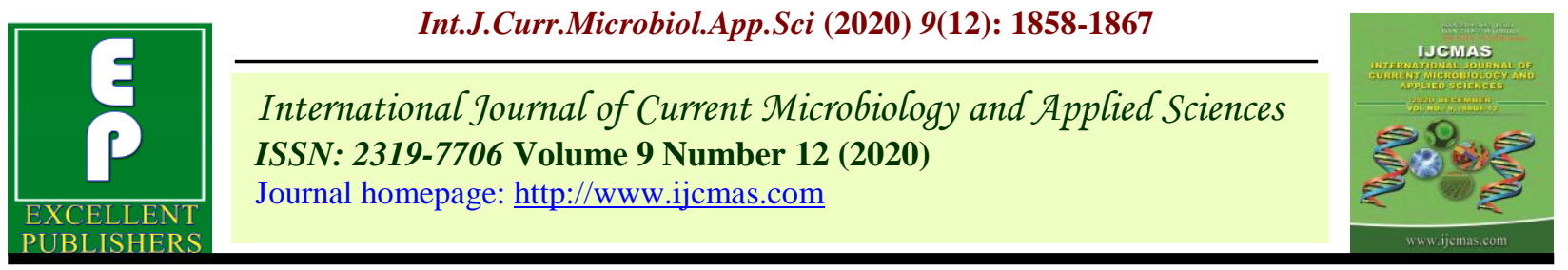

\title{
Effect of Different Rooting Media for Rooting Success and Survivability of Marcottage in Pomegranate (Punica granatum L.) C.V. Bhagwa
}

\author{
Intjar Singh Dawar*, T. R. Sharma, O. P. Nagar and Shreesty Pal \\ Department of Horticulture, College of Agriculture JNKVV, Jabalpur, (MP), India \\ *Corresponding author
}

\section{A B S T R A C T}

\begin{tabular}{l} 
K e y w o r d s \\
$\begin{array}{l}\text { Pomegranate } \\
\text { (Punica granatum }\end{array}$ \\
$\begin{array}{l}\text { L.), Vermicompost, } \\
\text { rooting media } \\
\text { Azospirillum, } \\
\text { Pseudomonas, } \\
\text { Survivability }\end{array}$ \\
Article Info \\
$\begin{array}{l}\text { Accepted: } \\
14 \text { November } 2020 \\
\text { Available Online: } \\
10 \text { December } 2020\end{array}$ \\
\hline
\end{tabular}

Keywords

Pomegranate L.), Vermicompost, rooting media Pseudomonas,

Article Info

Accepted:

Available Ont

Introduction

Pomegranate (Punica granatum L) is an ancient favourite table fruit of tropical regions of the world and it belongs to the family Punicaceae having chromosome no. $2 \mathrm{n}=18$. Plant is deciduous in desert regions, but in coastal areas may lose only a portion of its leaves in winter. Pomegranate comes under the fruit type "Balusta" and its edible part is juicy seed coat i.e. Arils. Pomegranate is a non climacteric fruit and it prefers well drained sandy loam to deep loamy soil types with hot and dry climatic condition during flowering and fruit development. It has been spread to other countries from Iran, its main producer and exporter in the world (Alikhani et al., 2011).

India ranks first in pomegranate production in the world but it has only $7 \%$ share of total world exports. The total area under cultivation of pomegranate in India is 220 thousand ha and production is around 2795 thousand MT with productivity of $10.3 \mathrm{MT} \mathrm{ha}^{-1}$ and in Maharashtra the cultivated area under this crop is 90 thousand ha and production is 945 thousand MT (Anon., 2014). Propagation 
through hard wood cuttings is also the best and less expensive method (Upadhyay and Badyal, 2007) but commercially air-layering is one of the most successful method in pomegranate propagation and has the advantage of being able to reproduce plants with better rooting than cuttings. The different rooting media and plant growth regulators (PGRs) played a major role in rooting. Different rooting media like sphagnum moss, coco peat and saw dust have higher moisture holding capacity with lighter weight, which enhance root formation (Bhosale et al., 2009). Use of root promoting chemicals or auxins such as IBA, IAA, and NAA are generally used to stimulate rooting in number of plants using there alone or in combination with auxin synergists (non auxin compounds). Among these auxins IBA is found often beneficial (Ram et al., 2005). Meagre work has been carried out with application of biofertilizer with PGR's, therefore the experiment entitled on Studies on Marcottage in Pomegranate (Punica granatum L.) protecting plants from phytopathogens by controlling or inhibiting them, improving soil structure and bioremediating the polluted soils by sequestering toxic heavy metal species and degrading xenobiotic compounds (like pesticides) (Ahemad, 2012; Hayat et al.,2010; Rajkumar et al., 2010; Braud et al., 2009).

\section{Materials and Methods}

\section{Experimental site}

The experiment was conducted at Fruit Research Station, Imalia, Department of Horticulture, College of Agriculture, J.N.K.V.V., Jabalpur, Madhya Pradesh, India. The experiment was conducted during the year 2018-2019. The experimental site was situated at $23.9^{\circ} \mathrm{N}$ latitude and $79.58^{\circ} \mathrm{E}$ longitude and an altitude of 411.78 meters above Mean Sea Level (MSL).

\section{Selection of plants}

For the experiment, select a plant that is uniform vigour and size. For air layering, we select a plant that is one year old and has a healthy branch and a panicle thickness. Forty five layers were prepared; the average length of branches was $40 \mathrm{~cm}$. for each treatment. A total of 15 shoots under each treatment were selected for layering. In all 900 layers were prepared for the study.

\section{Preparation of lanolin past of growth regulators}

The IBA quantity of $0.25,0.50$ and $0.75 \mathrm{~g}$ of IBA were weighed on electronic weighing balance, respectively. This quantity of IBA dissolved in about $10 \mathrm{cc}$ absolute alcohol and solution was mixed with desired quantity of lanoline paste.

\section{Preparation of rooting media}

$1 \mathrm{~kg}$ soil was taken by removing small stones and pebbles, Soil and Vermicompost were mixed in the ratio of $1: 1$ by volume, Soil + Vermicompost + Biofertilizer (Azotobacter Or Azospirillum Or Pseudomonas) were mixed thoroughly in the ratio of $500 \mathrm{gm}$ : 500gm: $2 \mathrm{gm}$ by volume, and then in all these water is added and mixed thoroughly to develop a friable medium.

\section{Method of treatment}

One-year old branches about pencil thickness were selected. A ring of bark about $2.5-3 \mathrm{~cm}$ in length was removed from selected shoot just below the bud without injuring the under lying wood. Then lanolin paste of IBA was applied and the respective rooting media was applied evenly around the cut portion as per the treatments then wrapped with polythene film and then tied with the help of jute rope. 


\section{Wrapping material}

Transparent polythene (200 gauge) was used as wrapper. The size of the polythene wrapper was $25 \times 20 \mathrm{~cm}^{2}$.

\section{Details of experiment}

In the present investigation fifteen healthy branches were selected under each treatment and replicated three times to form the Randomized Complete Block Design.

\section{Detachment of air layers}

After 75 days after air layering of the shoots were detachments. Shoots were detached by making a cut just below the lower end of the ringed surface with a sharp scatter. The polythene covers were removed gently and the successful air layers were planted in wellprepared polybag as per the layout plan.

\section{Observations recorded}

Prior to detachment: Out of 15 layers in each treatments and replication were tagged to take the observations.

Days to root appearance: The number of days taken for first root appearance in layering's from the day of layering was recorded by observing tagged shoots from each treatment under each replication.

Rooting percentage (\%): The number of rooted air layers was counted before detachment of air layered from the mother plants. The data was compiled successfully and rooting per cent was calculated after 75 days of layering by following formula:

Rooting $(\%)=\frac{\text { No. of rooted air layered plant }}{\text { Total no of air layers of treatment }} X 100$
Number of primary and secondary root: Numbers of primary and secondary roots of detachment layers were counted and average numbers of primary and secondary roots were computed.

Length of primary and secondary root (cm): The length of primary and secondary root was measured with the help of scale in $\mathrm{cm}$ from base up to tip and average length of primary and secondary roots were computed and presented in $\mathrm{cm}$.

Diameter of primary and secondary root $(\mathbf{m m})$ : The diameter of the primary and secondary root was measured in $\mathrm{mm}$. with the help of Vernier caliper and average dimeter of primary and secondary roots were computed and presented in $\mathrm{mm}$.

Growth Parameter (after transplanting): Rooted layers were planted in polybags which was filled with soil, river sand, and well decomposed FYM in the ratio of 1:1:1. These packets were arrange in three sets of each treatment following observation were recorded.

Success percentage of air layers (\%): After 60 and 90 days of transplantation in polybags the success percentage was calculated by following formula:

Success percentage of air layers $(\%)=\frac{\text { Total no, of success layer }}{\text { Total no,of layered planted }} \mathrm{X} 100$

Survival percentage of air layers (\%): After 120 days of transplantation in polybags the survival percentage was calculated by using following formula:

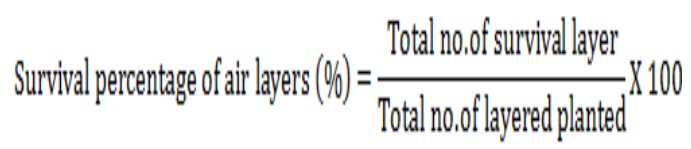


Height of layers (cm): The progressive height was measured at 60, 90 and 120 days after planting in polybags with the help of meter scale and average height of layers were computed and presented in $\mathrm{cm}$.

Number of branches: After 60, 90 and 120 days after transplanting in polybags the number of branches were counted and average numbers of branches were computed.

Number of leaves: At the time of layering planted in polybags, the number of leaves were counted after that progressive number were counted at 60,90 and 120 days after transplanting.

Length of leaves (cm): The mean length and width of leaves per air layers measured at 60 , 90 and 120 days of planting in polybags.

Leaf area index: LAI expresses the ratio of leaf surface considerably to the ground area occupied by the plant or a crop stand worked out as per specification of Gardner et al., (1985)

\section{Leaf Area Duration (LAD) $\left(\mathrm{cm}^{2}\right.$.days)}

Leaf Area Duration expresses the magnitude and persistence of leaf area of leafiness during the period of crop growth. It reflects the extent of period of crop growth. It reflects the extent of seasonal integral of light interaction and corrected with yield.

\section{Results and Discussion}

\section{Rooting parameter (Prior to detachment)}

\section{Days to root appearance}

The data regarding days taken to first root appearance as influenced by different growing media containing bio-inoculants and different concentrations of IBA is represented in the
Table 1. The interaction of soil media and IBA significantly affected the first root appearance and minimum days taken for first root appearance was recorded under $\mathrm{M}_{4} \mathrm{P}_{2}$ (Soil + Vermicompost + Azospirillum + IBA $5000 \mathrm{ppm})$ i.e. 16.46 days. The growth of roots increased with the 5000ppm concentration of IBA. The high concentration of IBA stimulated faster growth of roots resulting in maximum length as reported by Tyagi and Patel (2004).

\section{Rooting and growth parameter (After detachment)}

\section{Percentage of rooted layers $(\%)$}

The result of rooted layers as influenced by different growing media containing bioinoculants and different concentrations of IBA is represented in the Table 1. The maximum percentage of 97.77 rooted layers was recorded under $\mathrm{M}_{4} \mathrm{P}_{2}$ (Soil + Vermicompost + Azospirillum + IBA 5000ppm).

The spontaneous cell division and cell elongation stimulated by the rhizogenous activity of auxin increases the adventitious root formation. These findings are close conformity with the findings of (San Jose et al.(2012); Kang et al.(2014); Jutta et al.(2005).

\section{Number of primary roots}

The data regarding number of primary roots as influenced by different growing media containing bio-inoculants and different concentrations of IBA is represented in the Table 2. The number of primary roots and maximum number of primary roots of 16.40 was recorded under $\mathrm{M}_{4} \mathrm{P}_{2}$ (Soil + Vermicompost + Azospirillum + IBA 5000ppm). 
Table.1 Effect of PGR and soil media on appearance of first root in marcottage and Percentage of Rooted layers

\begin{tabular}{|c|l|c|c|}
\hline \multicolumn{2}{|c|}{ Treatments Details } & $\begin{array}{c}\text { Aappearance of } \\
\text { first root }\end{array}$ & $\begin{array}{c}\text { Percentage of } \\
\text { Rooted layers }\end{array}$ \\
\hline $\mathbf{T}_{\mathbf{1}}$ & Soil (control) & 27.90 & 46.66 \\
\hline $\mathbf{T}_{\mathbf{2}}$ & Soil+VC & 21.73 & 60.00 \\
\hline $\mathbf{T}_{\mathbf{3}}$ & Soil+VC+Azotobacter & 24.60 & 62.22 \\
\hline $\mathbf{T}_{\mathbf{4}}$ & Soil+VC+Azospiriillum & 24.33 & 66.66 \\
\hline $\mathbf{T}_{\mathbf{5}}$ & Soil+VC+Pseudomonas & 24.40 & 64.44 \\
\hline $\mathbf{T}_{\mathbf{6}}$ & Soil+IBA(2500ppm) & 27.66 & 66.66 \\
\hline $\mathbf{T}_{\mathbf{7}}$ & Soil+VC+IBA(2500ppm) & 19.20 & 68.88 \\
\hline $\mathbf{T}_{\mathbf{8}}$ & Soil+VC+Azotobacter+IBA(2500ppm) & 21.06 & 71.10 \\
\hline $\mathbf{T}_{\mathbf{9}}$ & Soil+VC+Azospirillum+IBA(2500ppm) & 20.46 & 80.00 \\
\hline $\mathbf{T}_{\mathbf{1 0}}$ & Soil+IVC+Pseudomonas+IBA(2500ppm) & 20.13 & 73.33 \\
\hline $\mathbf{T}_{\mathbf{1 1}}$ & Soil+IBA(5000ppm) & 19.33 & 80.00 \\
\hline $\mathbf{T}_{\mathbf{1 2}}$ & Soil+VC+IBA(5000ppm) & 21.13 & 82.22 \\
\hline $\mathbf{T}_{\mathbf{1 3}}$ & Soil+VC+Azotobacter+IBA(5000) & 18.13 & 86.66 \\
\hline $\mathbf{T}_{\mathbf{1 4}}$ & Soil+VC+Azospirillum+IBA(5000) & 16.46 & 97.77 \\
\hline $\mathbf{T}_{\mathbf{1 5}}$ & Soil+VC+Pseudomonas+IBA(5000) & 17.20 & 88.88 \\
\hline $\mathbf{T}_{\mathbf{1 6}}$ & Soil+IBA(7500ppm) & 21.53 & 66.66 \\
\hline $\mathbf{T}_{\mathbf{1 7}}$ & Soil+VC+IBA(7500ppm) & 19.93 & 68.88 \\
\hline $\mathbf{T}_{\mathbf{1 8}}$ & Soil+VC+Azotobacter+IBA(7500ppm) & 19.93 & 73.33 \\
\hline $\mathbf{T}_{\mathbf{1 9}}$ & Soil+VC+Azospirillum+IBA(7500ppm) & 21.40 & 80.00 \\
\hline $\mathbf{T}_{\mathbf{2 0}}$ & Soil+VC+Pseudomonas+IBA(7500ppm) & 22.00 & 80.00 \\
\hline & & $\mathbf{1 . 2 2}$ & $\mathbf{1 . 3 2}$ \\
\hline & SE(m)+ & $\mathbf{3 . 5 1}$ & $\mathbf{3 . 8 0}$ \\
\hline & C.D. at 5\% & & \\
\hline
\end{tabular}

Table.2 Effect of PGR and soil media on number of primary and secondary roots

\begin{tabular}{|c|l|c|c|}
\hline \multicolumn{2}{|l|}{ Treatments Details } & $\begin{array}{c}\text { Number of } \\
\text { primary root }\end{array}$ & $\begin{array}{c}\text { Number of } \\
\text { secondary root }\end{array}$ \\
\hline $\mathbf{T}_{\mathbf{1}}$ & Soil (control) & 10.86 & 25.8 \\
\hline $\mathbf{T}_{\mathbf{2}}$ & Soil+VC & 10.93 & 27.26 \\
\hline $\mathbf{T}_{\mathbf{3}}$ & Soil+VC+Azotobacter & 11.20 & 26.33 \\
\hline $\mathbf{T}_{\mathbf{4}}$ & Soil+VC+Azospiriillum & 13.40 & 26.46 \\
\hline $\mathbf{T}_{\mathbf{5}}$ & Soil+VC+Pseudomonas & 11.73 & 27.8 \\
\hline $\mathbf{T}_{\mathbf{6}}$ & Soil+IBA(2500ppm) & 9.66 & 26.46 \\
\hline $\mathbf{T}_{\mathbf{7}}$ & Soil+VC+IBA(2500ppm) & 11.86 & 26.26 \\
\hline $\mathbf{T}_{\mathbf{8}}$ & Soil+VC+Azotobacter+IBA(2500ppm) & 10.13 & 27.06 \\
\hline $\mathbf{T}_{\mathbf{9}}$ & Soil+VC+Azospirillum+IBA(2500ppm) & 10.53 & 26.8 \\
\hline $\mathbf{T}_{\mathbf{1 0}}$ & Soil+VC & 10.46 & 27.06 \\
\hline & IBA(2500ppdomonas+ & & \\
\hline $\mathbf{T}_{\mathbf{1 1}}$ & Soil+IBA(5000ppm) & 10.00 & 27.46 \\
\hline
\end{tabular}




\begin{tabular}{|l|l|c|c|}
\hline $\mathbf{T}_{\mathbf{1 2}}$ & Soil+VC+IBA(5000ppm) & 8.86 & 29.13 \\
\hline $\mathbf{T}_{\mathbf{1 3}}$ & Soil+VC+Azotobacter+IBA(5000) & 14.00 & 30.93 \\
\hline $\mathbf{T}_{\mathbf{1 4}}$ & Soil+VC+Azospirillum+IBA(5000) & 16.4 & 32.8 \\
\hline $\mathbf{T}_{\mathbf{1 5}}$ & Soil+VC+Pseudomonas+IBA(5000) & 15.53 & 30.4 \\
\hline $\mathbf{T}_{\mathbf{1 6}}$ & Soil+IBA(7500ppm) & 11.00 & 29.26 \\
\hline $\mathbf{T}_{\mathbf{1 7}}$ & Soil+VC+IBA(7500ppm) & 12.00 & 29.93 \\
\hline $\mathbf{T}_{\mathbf{1 8}}$ & Soil+VC+Azotobacter+IBA(7500ppm) & 12.86 & 31.66 \\
\hline $\mathbf{T}_{\mathbf{1 9}}$ & Soil+VC+Azospirillum+IBA(7500ppm) & 12.66 & 30.53 \\
\hline $\mathbf{T}_{\mathbf{2 0}}$ & Soil+VC+Pseudomonas+IBA(7500ppm) & 12.06 & 30.2 \\
\hline & SE(m) \pm & $\mathbf{0 . 1 4}$ & $\mathbf{0 . 4 9}$ \\
\hline & C.D. at 5\% & $\mathbf{0 . 4 0}$ & $\mathbf{1 . 4 3}$ \\
\hline
\end{tabular}

Table.3 Effect of PGR and soil media on length of primary, secondary roots and root length at 45 days after Layering

\begin{tabular}{|c|c|c|c|c|}
\hline \multicolumn{2}{|c|}{ Treatments Details } & $\begin{array}{l}\text { Length of primary } \\
\text { roots }(\mathrm{cm})\end{array}$ & $\begin{array}{l}\text { Length of } \\
\text { secondary } \\
\text { roots }(\mathrm{cm})\end{array}$ & $\begin{array}{l}\text { Root length } \\
\text { at } 45 \text { days } \\
\text { (cm) }\end{array}$ \\
\hline $\mathbf{T}_{1}$ & Soil (control) & 9.57 & 2.28 & 9.62 \\
\hline $\mathbf{T}_{2}$ & Soil+VC & 10.7 & 2.41 & 10.06 \\
\hline $\mathbf{T}_{3}$ & Soil+VC+Azotobacter & 10.26 & 3.48 & 10.59 \\
\hline $\mathbf{T}_{4}$ & Soil+VC+Azospiriillum & 12.34 & 3.54 & 11.62 \\
\hline $\mathbf{T}_{5}$ & Soil+VC+Pseudomonas & 10.38 & 3.16 & 11.52 \\
\hline$T_{6}$ & Soil+IBA(2500ppm) & 11.12 & 3.97 & 11.32 \\
\hline $\mathbf{T}_{7}$ & Soil+VC+IBA(2500ppm) & 11.39 & 3.3 & 11.53 \\
\hline $\mathbf{T}_{8}$ & Soil+VC+Azotobacter+IBA(2500ppm) & 11.54 & 4.29 & 11.41 \\
\hline $\mathbf{T}_{9}$ & Soil+VC+Azospirillum+IBA(2500ppm) & 11.82 & 4.08 & 11.56 \\
\hline$T_{10}$ & Soil+IVC +Pseudomonas+ IBA(2500ppm) & 12.52 & 5.06 & 12.06 \\
\hline$T_{11}$ & Soil+IBA(5000ppm) & 13.08 & 4.55 & 12.34 \\
\hline$T_{12}$ & Soil+VC+IBA(5000ppm) & 13.72 & 4.54 & 13.96 \\
\hline$T_{13}$ & Soil+VC+Azotobacter+IBA(5000) & 12.85 & 5.39 & 14.76 \\
\hline $\mathbf{T}_{14}$ & Soil+VC+Azospirillum+IBA(5000) & 14.2 & 6.28 & 15.88 \\
\hline $\mathbf{T}_{15}$ & Soil+VC+Pseudomonas+IBA(5000) & 13.11 & 6.07 & 15.25 \\
\hline $\mathbf{T}_{16}$ & Soil+IBA(7500ppm) & 13.08 & 5.64 & 12.62 \\
\hline $\mathbf{T}_{17}$ & Soil+VC+IBA(7500ppm) & 13.08 & 5.38 & 13.22 \\
\hline $\mathbf{T}_{18}$ & Soil+VC+Azotobacter+IBA(7500ppm) & 13.11 & 5.64 & 13.16 \\
\hline $\mathbf{T}_{19}$ & Soil+VC+Azospirillum+IBA(7500ppm) & 13.52 & 5.14 & 13.48 \\
\hline $\mathbf{T}_{20}$ & Soil+VC+Pseudomonas+IBA(7500ppm) & 13.44 & 4.33 & 13.58 \\
\hline \multicolumn{2}{|r|}{$\mathrm{SE}(\mathbf{m}) \pm$} & 0.303 & 0.319 & 0.188 \\
\hline \multicolumn{2}{|r|}{ C.D. at 5\% } & 0.87 & 0.916 & 0.539 \\
\hline
\end{tabular}


Table.4 Effect of PGR and soil media on diameter of primary and secondary roots

\begin{tabular}{|c|c|c|c|}
\hline \multicolumn{2}{|c|}{ Treatments Details } & \multirow{2}{*}{$\begin{array}{c}\begin{array}{c}\text { diameter of } \\
\text { primary root } \\
(\mathbf{m m})\end{array} \\
0.15\end{array}$} & \multirow{2}{*}{$\begin{array}{c}\begin{array}{c}\text { diameter of } \\
\text { secondary root } \\
\text { (mm) }\end{array} \\
0.3\end{array}$} \\
\hline $\mathbf{T}_{1}$ & Soil (control) & & \\
\hline $\mathbf{T}_{2}$ & Soil+VC & 0.22 & 0.75 \\
\hline $\mathbf{T}_{3}$ & Soil+VC+Azotobacter & 1.15 & 0.29 \\
\hline $\mathbf{T}_{4}$ & Soil+VC+Azospiriillum & 0.57 & 0.43 \\
\hline $\mathbf{T}_{5}$ & Soil+VC+Pseudomonas & 0.62 & 0.25 \\
\hline $\mathbf{T}_{6}$ & Soil+IBA(2500ppm) & 0.83 & 1.52 \\
\hline $\mathbf{T}_{7}$ & Soil+VC+IBA(2500ppm) & 0.92 & 1.24 \\
\hline $\mathbf{T}_{8}$ & Soil+VC+Azotobacter+IBA(2500ppm) & 1.23 & 1.08 \\
\hline$T_{9}$ & Soil+VC+Azospirillum+IBA(2500ppm) & 1.12 & 1.30 \\
\hline $\mathbf{T}_{10}$ & Soil+VC +Pseudomonas+ IBA(2500ppm) & 1.21 & 1.36 \\
\hline$T_{11}$ & Soil+IBA(5000ppm) & 1.24 & 1.50 \\
\hline $\mathbf{T}_{12}$ & Soil+VC+IBA(5000ppm) & 1.13 & 1.64 \\
\hline $\mathbf{T}_{13}$ & Soil+VC+Azotobacter+IBA(5000) & 1.58 & 2.02 \\
\hline $\mathbf{T}_{14}$ & Soil+VC+Azospirillum+IBA(5000) & 4.01 & 2.20 \\
\hline $\mathbf{T}_{15}$ & Soil+VC+Pseudomonas+IBA(5000) & 3.07 & 2.10 \\
\hline $\mathbf{T}_{16}$ & Soil+IBA(7500ppm) & 1.15 & 1.19 \\
\hline $\mathbf{T}_{17}$ & Soil+VC+IBA(7500ppm) & 1.39 & 0.96 \\
\hline $\mathbf{T}_{18}$ & Soil+VC+Azotobacter+IBA(7500ppm) & 1.32 & 1.95 \\
\hline $\mathbf{T}_{19}$ & Soil+VC+Azospirillum+IBA(7500ppm) & 1.29 & 1.99 \\
\hline $\mathbf{T}_{20}$ & Soil+VC+Pseudomonas+IBA(7500ppm) & 1.14 & 1.80 \\
\hline \multicolumn{2}{|r|}{$\mathrm{SE}(\mathbf{m}) \pm$} & 0.17 & 0.114 \\
\hline \multicolumn{2}{|r|}{ C.D. at $5 \%$} & 0.48 & 0.328 \\
\hline
\end{tabular}

Table.5 Effect of PGR and growing media on Success of layer (\%) at 60 and 90 DAT and Survival of marcottage $(\%)$ at 120 days

\begin{tabular}{|c|l|c|c|c|}
\hline \multicolumn{2}{|l|}{ Treatments Details } & $\begin{array}{c}\text { Success (\%) } \\
\text { at 60 DAT }\end{array}$ & $\begin{array}{c}\text { Success (\%) } \\
\text { at 90 DAT }\end{array}$ & $\begin{array}{c}\text { Survival (\%) } \\
\text { at 120 days }\end{array}$ \\
\hline $\mathbf{T}_{\mathbf{1}}$ & Soil (control) & 46.66 & 46.67 & 40 \\
\hline $\mathbf{T}_{\mathbf{2}}$ & Soil+VC & 53.33 & 53.33 & 53.33 \\
\hline $\mathbf{T}_{\mathbf{3}}$ & Soil+VC+Azotobacter & 53.33 & 40 & 46.66 \\
\hline $\mathbf{T}_{\mathbf{4}}$ & Soil+VC+Azospiriillum & 53.33 & 46.67 & 46.66 \\
\hline $\mathbf{T}_{\mathbf{5}}$ & Soil+VC+Pseudomonas & 53.33 & 53.33 & 53.33 \\
\hline $\mathbf{T}_{\mathbf{6}}$ & Soil+IBA(2500ppm) & 66.66 & 60 & 60.00 \\
\hline $\mathbf{T}_{\mathbf{7}}$ & Soil+VC+IBA(2500ppm) & 73.33 & 66.67 & 60.00 \\
\hline $\mathbf{T}_{\mathbf{8}}$ & Soil+VC+Azotobacter+IBA(2500ppm) & 80 & 80 & 73.33 \\
\hline $\mathbf{T}_{\mathbf{9}}$ & Soil+VC+Azospirillum+IBA(2500ppm) & 60 & 60 & 60.00 \\
\hline $\mathbf{T}_{\mathbf{1 0}}$ & Soil+IVC+Pseudomonas+IBA(2500ppm) & 66.66 & 60 & 60.00 \\
\hline
\end{tabular}




\begin{tabular}{|c|l|c|c|c|}
\hline $\mathbf{T}_{\mathbf{1 1}}$ & Soil+IBA(5000ppm) & 60 & 60 & 60.00 \\
\hline $\mathbf{T}_{\mathbf{1 2}}$ & Soil+VC+IBA(5000ppm) & 80 & 73.33 & 73.33 \\
\hline $\mathbf{T}_{\mathbf{1 3}}$ & Soil+VC+Azotobacter+IBA(5000) & 86.66 & 80 & 73.33 \\
\hline $\mathbf{T}_{\mathbf{1 4}}$ & Soil+VC+Azospirillum+IBA(5000) & 100 & 93.33 & 93.33 \\
\hline $\mathbf{T}_{\mathbf{1 5}}$ & Soil+VC+Pseudomonas+IBA(5000) & 93.33 & 86.67 & 80.00 \\
\hline $\mathbf{T}_{\mathbf{1 6}}$ & Soil+IBA(7500ppm) & 66.66 & 80 & 73.33 \\
\hline $\mathbf{T}_{\mathbf{1 7}}$ & Soil+VC+IBA(7500ppm) & 73.33 & 60 & 60.00 \\
\hline $\mathbf{T}_{\mathbf{1 8}}$ & Soil+VC+Azotobacter+IBA(7500ppm) & 66.66 & 60 & 60.00 \\
\hline $\mathbf{T}_{\mathbf{1 9}}$ & Soil+VC+Azospirillum+IBA(7500ppm) & 80 & 60 & 60.00 \\
\hline $\mathbf{T}_{\mathbf{2 0}}$ & Soil+VC+Pseudomonas+IBA(7500ppm) & 73.33 & 66.67 & 66.66 \\
\hline & SE(m) \pm & $\mathbf{5 . 3 3}$ & $\mathbf{4 . 5 7}$ & $\mathbf{6 . 7 7}$ \\
\hline & C.D. at 5\% & $\mathbf{1 5 . 3 2}$ & $\mathbf{1 3 . 1 5}$ & $\mathbf{1 3 . 7 6}$ \\
\hline
\end{tabular}

\section{Number of secondary roots}

The results regarding the number of secondary roots as influenced by different growing media containing bio-inoculants and different concentrations of IBA is represented in the Table 2. The number of secondary roots and maximum number of 32.80 secondary roots was recorded under Soil + Vermicompost + Azospirillum + IBA $5000 \mathrm{ppm}\left(\mathrm{M}_{4} \mathrm{P}_{2}\right)$ The beneficial effect of suppression of deleterious bacteria and stimulation of root development by the production of rhizosphere population by azospirillum also resulted for increase in the length and number of primary and secondary roots (Hartman et al., 1983; Rivka and Yacov1987).

\section{Length of primary root $(\mathrm{cm})$}

The data regarding length of primary roots as influenced by different growing media containing bio-inoculants and different concentrations of IBA is represented in the Table 3. The number of primary roots and maximum primary roots length of $14.20 \mathrm{~cm}$ was recorded under $\left(\mathrm{M}_{4} \mathrm{P}_{2}\right)$ Soil + Vermicompost + Azospirillum + IBA 5000ppm).

\section{Length of secondary root $(\mathrm{cm})$}

The results on the length of secondary roots as influenced by different growing media containing bio-inoculants and different concentrations of IBA is represented in the Table 3. The number of secondary roots and maximum length of secondary roots of 6.28 $\mathrm{cm}$ was recorded under $\mathrm{M}_{4} \mathrm{P}_{2}$ (Soil + Vermicompost + Azospirillum + IBA 5000ppm).

The nutrients needed for root growth and development were well provided by soil and Vermicompost (Urmi et al., 2016). Hartman et al., (1983) reported that the production of growth-regulating substances by the bacterium results in more cell division in roots.

\section{Root length at 45 days after layering (cm)}

The results on the root length at 45 days after layering as influenced by different growing media containing bio-inoculants and concentrations of IBA is represented in the Table 3. The root length where as the longest root and maximum length of $15.88 \mathrm{~cm}$ root was recorded under $\mathrm{M}_{4} \mathrm{P}_{2}$ (Soil + Vermicompost + Azospirillum + IBA 5000 ppm). 


\section{Diameter of primary and secondary roots (mm)}

The result on the diameter of primary and secondary roots as influenced by different growing media containing bio-inoculants and different concentration of IBA is represented in the Table 4 . The diameter of primary and secondary roots, Maximum diameter of primary roots of $(4.01 \mathrm{~mm})$ and secondary roots $(2.20 \mathrm{~mm})$ was recorded under $\mathrm{M}_{4} \mathrm{P}_{2}$ (Soil + Vermicompost + Azospirillum + IBA $5000 \mathrm{ppm})$.

\section{Success of layer (\%)}

The success percentage of layers at 60 and 90 days after transplanting was recorded and presented in Table 5. The maximum success percentage 100 and 93.33 per cent was recorded under $\mathrm{M}_{4} \mathrm{P}_{2}$ (Soil + Vermicompost + Azospirillum + IBA 5000ppm) at 60 and 90 days after transplanting, respectively.

\section{Survival of marcottage (\%)}

The results on survival percentage as influenced by different growing media containing bio-inoculants and concentrations of IBA is represented in the Table 5. The survival percentage whereas, maximum marcottage survival percentage 93.33 was noted under $\mathrm{M}_{4} \mathrm{P}_{2}$ (Soil + Vermicompost + Azospirillum + IBA 5000ppm). The higher success and survival percentage of layers under treatment soil + Vermicompost + Azospirillum+IBA5000ppm may be due to more number and length of primary and secondary roots, this resulted in better absorption of nutrients and moisture from the soil (Tyagi and Patel. 2004).

\section{Acknowledgement}

The author wish to thank the research guide and Head of the Department and staff of
Horticulture, Jawaharlal Nehru Krishi Vishwa Vidyalaya, Jabalpur, Madhya Pradesh for providing necessary facility in conducting the experiment. Special thanks to the family members and friends for their unconditional support.

\section{References}

Anon (2017). Indian Horticulture Database, National Horticulture Board, Ministry of Agriculture, Govt. of India. Cuttings Horticulture. Journal, 17(1): 41-47.

Alikhani, L., Ansari, K., Jamnezhad, M. and Tabatabaie, Z. (2011). The effect of different mediums and cuttings on growth and rooting of pomegranate cuttings. Iran. Journal. of Plant Physiology, 1(3): 199203.

Bibha K. and Suraj P. (2017). Economics of plant prepared through air layers of guava (Psidium guajava L.). International Journal of Agriculture Science and Research, 7(2): 313-318.

Bhosale, V. P., Jadhav, R.G. and Masu, M.M. (2009). Response of different medias and PGR"s on rooting and survival of air layers in pomegranate (Punica granatum L.) Cv. Sindhuri. The Asian Journal of Horticulture, 4(2): 494-497.

Chawla, W., Mehta, K. and Chauhan, M. (2012). Influence of plant growth regulators on rooting of litchi (Litchi chinensis Sonn.) air layers. The Asian Journal of Horticulture, 7(1): 160-164.

Das, A. K. and Prasad, B. (2014). Effect of plant growth regulators on rooting and survival of air layering in Litchi. Advance Research Journal of crop Improvement, 5(2): 126-130.

Erdag, B. B., Emek, Y.C. and Aydogan, S.K. (2010). Clonal propagation of Dorystoech as hastatavia axillary shoot proliferation. Turk. Journal. Bot., 34(3): 233-240.

Jutta LM, Vertocnik A and Christopher D and Town (2005). Analysis ofindole-3-butyric acid-induced adventitious root formations on Arabidopsis stem segments. Journal of Experimental Botany, 56(4): 21-25.

Kang W, Li-Yuan W, Li-Yun W, Cheng-Cai Z, 
Hai-Lin L, Li-Qiang T, Hong-Li C and Hao C. (2014). Transcriptome Analysis of Indole-3-Butyric

Acid-Induced

Adventitious Root Formation in Nodal Cuttings of Camellia sinensis (L.). Plos One, 9(9): 107-201.

Khalid M, Bilal M, Danial H, Hafiz MNI, Hang W and Danfeng H. (2017). Mitigation of salt stress in white clover (Trifolium repens) by Azospirillum brasilense and its inoculation effect. Botanical Studies.5:58.

Munde,G.R., Nainwad, R.V., Maske, S.N. and Pawar, J.V. (2016). Effect of IBA and other chemicals on air layering in Pomegranate Cv.Bhagwa. BIOINFOLET, 13(2A): 291-293.

Mustafa E, Al-Hadethi A, Ali ST, AL-Dulaimi and Almashhadani BMK (2017). Influence of biofertilizers on growth and leaf mineral content in peach transplants. Journal of Agriculture and Veterinary Science, 10(9): 90-93.

Rivka H and Yaacov O. (1987). Effect of Azospirillum brasilense inoculation on root morphology and respiration in tomato seedlings. Biol Fertil Soils, 5: 241-247

Ram, R.B., Kumar, P. and Kumar, A. (2005). Effect of IBA and PHB on regeneration of pomegranate (Punica granatum L.) through stem cuttings. New Agriculturist, 16(1,2): 113-122.

Reddy,. P.N., Ray, N.R., Patel, A.D. and Patel, J.S. (2014). Effect of rooting media and IBA levels on rooting and survival of air layering in fig (Ficus carica L.) Cv. Poona
Fig under middle Gujrat agro climatic conditions. The Asian Journal of Horticulture, 9(1): 1-5.

Singh, M. (2001). Efficacy of plant growth regulators, their concentrations and wrappers on rooting success and survival of air-layered guava twigs (Psidium gujavaL.). Crop Res., Hisar, 21(2): 153156.

San Jose MC, Romero L and Janeiro LV. (2012). Effect of indole-3-butyric acid on root formation in Alnusglutinosa microcuttings. Silva Fennica, 46(5): 643654.

Tyagi, S. K. and Patel, R.M. (2004). Effect of growth regulators on rooting of air layering of guava (Psidium guajava L.) Cv. Sardar. Orissa Journal of Horticulture, 32(1): 58-62.

Upadhyay, S.K. and Badyal, J. (2007). Effect of growth regulators on rooting of pomegranate (Punica granatum L.) cutting. Haryana Journal of Horticulture Science, 36(1\& 2): 58-59.

Urmi FF, Malek MA, Ali M and Rahman MS (2016). Effect of operational time and rooting media on success and survivability of air layering in guava. Journal Patuakhali Science and Technology, 7(1\&2): 1-10.

Vidhyasekaran, P. (2007). Plant defense activators: precise application technology. Hand-book of Molecular Technologies in Crop Disease Management. New York: Haworth Press.

\section{How to cite this article:}

Intjar Singh Dawar, T. R. Sharma, O. P. Nagar and Shreesty Pal. 2020. Effect of Different Rooting Media for Rooting Success and Survivability of Marcottage in Pomegranate (Punica granatum L.) C.V. Bhagwa. Int.J.Curr.Microbiol.App.Sci. 9(12): 1858-1867. doi: https://doi.org/10.20546/ijcmas.2020.912.221 